\title{
Remembering over 400 Years of Black Racial Trauma and Asking Where Do We Go from Here?
}

\author{
Ruby Mendenhall* \\ Associate professor of sociology and African American Studies at the University of Illinois, USA \\ *Corresponding author: Ruby Mendenhall, Associate professor of sociology and African American Studies at the University of \\ Illinois and Assistant Dean of the Carle Illinois College of Medicine, Illinois, USA
}

\section{Opinion}

In 2019, many Americans commemorated 400 years of Black racial trauma. We retold and re-enacted the history of inhumanity and brutality starting with the arrival of over 20 Africans in August 1619 in Jamestown, Virginia.

We reflected on the legacy of slavery and its aftermath and revisited American ideologies and practices that allowed the institution of slavery to flourish and cast tentacles of oppression 400 years into the future. Take housing inequality, which historian Richard Rothstein calls a relic of slavery in The Color of Law, which the Civil Rights Act of 1866 sought to address by banning discriminatory actions that made blacks second-class citizens. In 1968, the Supreme Court "recognized the validity of the 1866 Civil Rights Act's declaration that housing discrimination was a residue of slave status that the $13^{\text {th }}$ Amendment empowered Congress to eliminate," according to Rothstein.

Fast forward to 2010, when over 50\% of blacks experienced high levels of residential segregation or hyper segregation. And just recently, a Chicago Lawyers' Committee for Civil Rights report found landlords through the city routinely violate fair housing laws, which limits housing options for black residents. Housing, is just one example of the malicious nature of structured racism. Socioeconomic factors are linked to stark disparities in health outcomes along racial, gender and educational lines. During AllStar weekend in Chicago (February 2020), 25 people were shot and 11 of them were children. With such glaring relics of inequality, where do we go from here?

It seems like a big ask to suggest investing millions of dollars to address socioeconomic inequality and to promote the healing of racial trauma. Consider the possibilities to create culturally specific wellness campaigns, decrease stigma around mental health challenges and direct individuals to treatment programs. For those who say a radical transformation of black mental wellness cannot be done, there are groups across the country already working to make this a reality. Informed by black organizations, such a powerful investment could include academic disciplines, social and political organizations, and religious institutions.

Chicago needs this. This toxic stress is a relic of inequality and collectively we can create transformative changes. African American history is full of examples of resilience despite exposure to high levels of stress and oppression. Our ancestors' personal and spiritual power carved out a pathway for us to walk in our humanity.

In 2017, I went to Ghana and walked through the "door of no return" and remember thinking the name of the door does not capture the complete story. I had returned to Africa. I had my ancestors' DNA, their beautiful brown skin, their full lips, their kinky hair, their stories and other ways of being that I may not be able to identify. As I walked through the door, I felt them walk with me. This time, they walked in their true nature as free dignified humans.

As we walk in time away from the 400th year of remembering America's role in Black racial trauma, investing in jobs, education, safe and affordable housing would go a long way in 2020. We must boldly leverage our resilience, recognize the dignity of black humanity, and eradicate the physical and mental relics of slavery for now and the next 400 years. 
(C) (i) This work is licensed under Creative

To Submit Your Article Click Here: Submit Article

DOI: $10.32474 / J A A S .2020 .01 .000122$

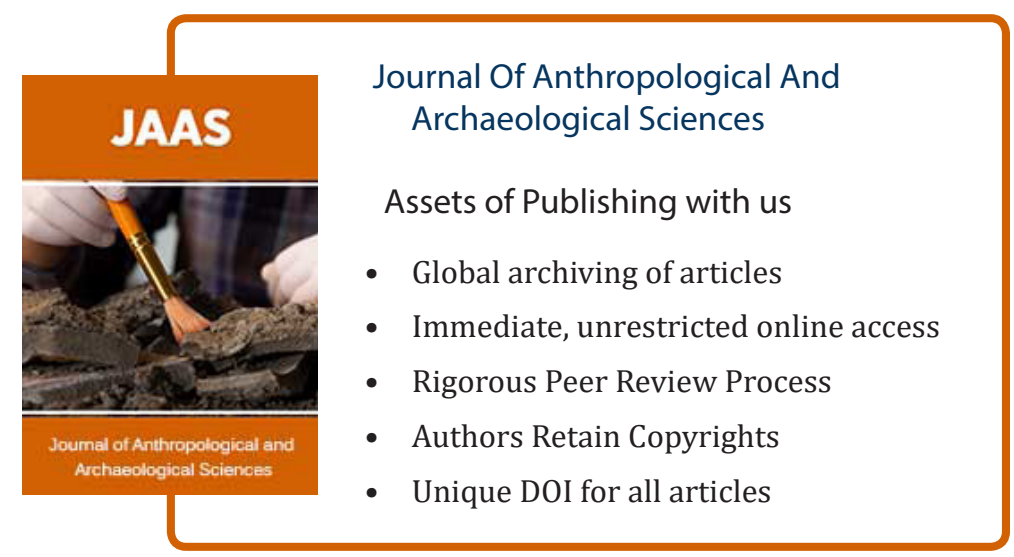

